\title{
Rod Photoreceptors Protect from Cone Degeneration- Induced Retinal Remodeling and Restore Visual Responses in Zebrafish
}

\author{
Carole J. Saade, ${ }^{1,2}$ Karen Alvarez-Delfin, ${ }^{1}$ and James M. Fadool ${ }^{1,2}$ \\ ${ }^{1}$ Department of Biological Science and ${ }^{2}$ Program in Neuroscience, The Florida State University, Tallahassee, Florida 32306
}

\begin{abstract}
Humans are largely dependent upon cone-mediated vision. However, death or dysfunction of rods, the predominant photoreceptor subtype, results in secondary loss of cones, remodeling of retinal circuitry, and blindness. The changes in circuitry may contribute to the vision deficit and undermine attempts at restoring sight. We exploit zebrafish larvae as a genetic model to specifically characterize changes associated with photoreceptor degenerations in a cone-dominated retina. Photoreceptors form synapses with two types of second-order neurons, bipolar cells, and horizontal cells. Using cell-specific reporter gene expression and immunolabeling for postsynaptic glutamate receptors, significant remodeling is observed following cone degeneration in the $p d e 6 c^{w 59}$ larval retina but not rod degeneration in the Xops:mCFP ${ }^{q 13}$ line. In adults, rods and cones are present in approximately equal numbers, and in $p d e 6 c^{w 59}$ mutants glutamate receptor expression and synaptic structures in the outer plexiform layer are preserved, and visual responses are gained in these once blind fish. We propose that the abundance of rods in the adult protects the retina from cone degeneration-induced remodeling. We test this hypothesis by genetically manipulating the number of rods in larvae. We show that an increased number and uniform distribution of rods in $l o r / t b x 2 b^{p 25 b b t l}$ or $s i x 7$ morpholino-injected larvae protect from $p d e 6 c^{w 59}$-induced secondary changes. The observations that remodeling is a common consequence of photoreceptor death across species, and that in zebrafish a small number of surviving photoreceptors afford protection from degeneration-induced changes, provides a model for systematic analysis of factors that slow or even prevent the secondary deteriorations associated with neural degenerative disease.
\end{abstract}

\section{Introduction}

Retinitis pigmentosa (RP) and allied dystrophies represent a heterogeneous collection of heritable diseases that progressively diminish the function and survival of retinal photoreceptors (http://www.sph.uth.tmc.edu/Retnet/disease.htm; Berson et al., 2002; Breuer et al., 2002; Rivolta et al., 2002). Early molecular findings raised new questions such as how mutations in genes expressed exclusively by rods lead to secondary, yet irreversible loss of the cones (Papermaster, 1995). Furthermore, in humans and mammalian models, photoreceptor death, retinal detachment, or lack of synaptic transmission result in remodeling of retinal circuitry and altered neurotransmitter receptor expression (Lewis et al., 1998; Strettoi and Pignatelli, 2000; Strettoi et al.,

Received June 19, 2012; revised Nov. 13, 2012; accepted Nov. 27, 2012.

Author contributions: C.J.S., K.A.-D., and J.M.F. designed research; C.J.S. and J.M.F. performed research; K.A.-D. contributed unpublished reagents/analytic tools; C.J.S. and J.M.F. analyzed data; C.J.S. and J.M.F. wrote the paper.

This work is supported by National Institutes of Health Grants R01 EY017753 (J.M.F.) and F31 EY020106 (K.A.D.) and a Florida State University Neuroscience Program Fellowship (C.J.S.). Ribeye-b antiserum was kindly provided by Dr. Teresa Nicolson, Oregon Health and Science University. GAD 65/67 antiserum was a generous gift from Dr. Jeffrey L. Goldberg, University of Miami Miller School of Medicine. We thank Stephen Yazulla for his helpful suggestions regarding immunolabeling. We also thank Dr. Alon Kahana and Daniel Kasprick for advice regarding adaptation of the OKR test to adult zebrafish. Additional thanks to Tyler Scott for fish care, Charles Badland for assistance with preparation of the figures, and the staff of the Biological Science Imaging Resource facility.

The authors declare no conflicting financial interests.

Correspondence should be addressed to Dr. James M. Fadool, Department of Biological Science, Florida State University, 3018 Life Science Building, Tallahassee, FL 32306-4295. E-mail: jfadool@bio.fsu.edu.

DOI:10.1523/JNEUROSCI.2910-12.2013

Copyright $\odot 2013$ the authors $\quad 0270-6474 / 13 / 331804-11 \$ 15.00 / 0$
2002; Fisher and Lewis, 2003; Haverkamp et al., 2006; Gargini et al., 2007; Sullivan et al., 2007), which may contribute to visual deficits and undermine attempts at restoring vision through stem cell therapy or retinal prostheses.

Experiments using zebrafish have made important contributions toward our understanding of retinal development, disease, and regeneration (Malicki et al., 1996; Fadool et al., 1997; Li and Dowling, 1997; Neuhauss et al., 1999; Vihtelic and Hyde, 2000; Bernardos et al., 2007; Ramachandran et al., 2010). The zebrafish is diurnal; its retina contains a large proportion of diverse cone subtypes in addition to rods. We previously characterized two lines of zebrafish demonstrating exclusive rod or cone degeneration. The Xops:mCFP ${ }^{q 13}$ transgenic line displays rapid and selective rod degeneration, opsin mislocalization, and loss of rodmediated electrophysiological responses, but unlike mammalian models of RP, cones are morphologically and physiologically unaffected (Morris et al., 2005). In the second, an allele of cone phosphodiesterase, $p d e 6 c^{w 59}$, results in rapid degeneration of cones in larvae and adults, and in larvae, the sparse rods become dystrophic, strikingly similar to the fate of cones following rod death in mammals. However, in pde $6 c^{w 59}$ juveniles and adults, the rods persist, leading us to propose that the density of photoreceptors is critical to their preservation (Stearns et al., 2007). This was tested in zebrafish chimeras in which clusters of wildtype (WT) photoreceptors in $p d e 6 c^{w 59}$ mutants persist up to 21 days postfertilization (dpf; Lewis et al., 2010), and corroborated by a recent report in this journal demonstrating long-term, rod- 
independent cone survival in the all cone $\mathrm{Nr}$ - /- mouse (Roger et al., 2012).

In the present study, we took advantage of rod- and conespecific degeneration in zebrafish to explicitly examine degeneration-induced remodeling in a cone-dominated retina and test the hypothesis that surviving photoreceptors protect from degeneration-induced remodeling. We show that in the larval retina, degeneration of cones, but not rods, results in significant remodeling of the retinal circuitry, yet in adults, with the abundance of rods, the outer plexiform layer (OPL) is preserved, cone degeneration-induced remodeling is minimized, and visual responses are gained in these previously blind fish. Taking advantage of loci affecting photoreceptor cell number, we show that an increased number and uniform distribution of rods in $p d e 6 c^{w 59}$ mutant larvae protect bipolar and horizontal cells from the cone degeneration-induced alterations. These data point to an avenue for preventing secondary changes during photoreceptor loss and potentially delaying vision deficits.

\section{Materials and Methods}

Zebrafish maintenance. Rearing, breeding, and staging of zebrafish (Danio rerio) were performed according to standard methods (Westerfield, 1995). Experiments and procedures were approved by the University Animal Care and Use Committee. Both male and female animals were used throughout the study. Animals were reared in a 14/10 h light/ dark cycle. The $T g$ (XRho:gap43-CFP $)^{q 13}$ line, referred to here as the Xops: $\mathrm{mCFP}^{q 13}$ line expresses a variant form of cyan fluorescent protein (CFP) in rod photoreceptors that encodes a palmitoylation signal sequence involved in the targeting of CFP to the plasma membrane. mCFPexpressing rods are apoptotic between 3 and $5 \mathrm{dpf}$. Cones remain intact and fully functional (Morris et al., 2005). The $p d e 6 c^{w 59}$ mutant line exhibits a non-sense mutation in the cone phosphodiesterase ( $p d e 6 c$ ) gene, resulting in cone degeneration starting at $4 \mathrm{dpf}$ (Stearns et al., 2007). The transgenic line $\operatorname{Tg}(U A S: g a p 43-Y F P)^{916 b}$; $\operatorname{Tg}(\text { nyx:Gal4-VP16 })^{916 a}$, referred to as nyx:mYFP ${ }^{q 16}$, was used to examine bipolar cells. In this transgenic line, sequences from a $n y x$ promoter drive the expression of membrane-targeted yellow fluorescent protein (mYFP) in a subset of ON bipolar cells (Schroeter et al., 2006). The nyx:mYFP ${ }^{q 16}$ transgenic line was bred onto each of the Xops:mCFP ${ }^{q 13}$ and $p d e 6 c^{w 59}$ lines. lots-of-rods $\left(\right.$ lor $\left.{ }^{p 25 b b t l}\right)$ is an allele of $t b x 2 b$, a T-box transcription factor. The lor/ tbx $2 b^{p 25 b b t l}$ mutation results in an increase in the number of rods across the entire retina, at the expense of SWS1 cones, the likely homologs of the short cones in mammals (Alvarez-Delfin et al., 2009).

pde $6 c^{w 59}$ mutant larvae and $p d e 6 c^{w 59} / \mathrm{Xops}: \mathrm{mCFP}^{q 13}$ larvae were isolated from matings of doubly heterozygous fish based upon the lack of the optokinetic response (OKR) at $6 \mathrm{dpf}$. Nonresponders and responders were then reared to adults and their genotype confirmed by PCR and sequence analysis. The sequences of the PCR primers were as follows: pde $6 c$ forward 5'-TTGACCAGAACCCGGAAGACT-3'; pde6c reverse 5'-CAGTTCAAAGAAGCAGCGAATG-3'; green fluorescent protein (GFP) forward 5' -ACGGCAAGCTGACCCTGAAG-3'; GFP reverse 5' GGGTGCTCAGGTAGTGGTTG-3'. The $p d e 6 c^{w 59}$ mutation was identified as a single nucleotide change (A to $\mathrm{G}$ ) between WT and mutant genomic DNA, as described by Stearns et al. (2007).

Histology. Immunohistochemistry was performed essentially as described previously (Morris et al., 2005). Briefly, fish were euthanized with tricaine $(4 \mathrm{mg} / \mathrm{ml})$. Intact larvae 3-8 dpf and freshly dissected adult retinas were fixed overnight at $4^{\circ} \mathrm{C}$ in $4 \%$ paraformaldehyde (PFA) in $80 \%$ PBS, pH 7, cryoprotected in sucrose, mounted in OCT medium (Tissue-Tek; Sakura), and frozen in a $-80^{\circ} \mathrm{C}$ freezer. Ten micrometer sections were mounted on gelatin-coated glass slides. Before immunolabeling, sections were postfixed in 1\% PFA for $10 \mathrm{~min}$ at room temperature, washed in PBS and two washes in PBST (0.05\% Tween-20), blocked in $1 \%$ bovine serum albumin in PBST, and sequentially incubated in primary antibody, species-specific fluorescent dye-conjugated secondary antibody, counterstained with Syto61 (Invitrogen; 1:15,000), and mounted in 50\% glycerol in PBST. The following primary antibodies and dilutions were used with this protocol: 4C12 (mouse, 1:20) to label rods (Alvarez-Delfin et al., 2009) and zpr-1 (mouse, 1:20) to label red and green cones (Zebrafish International Resource Center). Alexa Fluorconjugated secondary antibodies (Invitrogen) were used at a dilution of 1:200. Fixation and immunolabeling for the glutamate receptors GluR4 (rabbit, 1:10) and GluR2 (mouse, 1:75) (Millipore), GAD 65/67 (rabbit, 1:500) (Sigma-Aldrich) (generous gift from Dr. Jeffrey L. Goldberg, University of Miami Miller School of Medicine), and Ribeye-b (rabbit, 1:400) (generous gift from Dr. Teresa Nicolson, Oregon Health and Science University, Vollum Institute) as described by Klooster et al. (2009) was followed.

Morpholino injections. Morpholino (MO) antisense oligonucleotide targeting the six7 5'UTR with the sequence 5' CCAACGGCATTCCAGTGTGAGTAAC 3' (Inbal et al., 2007) was injected into one-cell stage embryos of a $p d e 6 c^{w 59}$ heterozygous cross. six7 MO stock was prepared at $1.25 \mathrm{ng} / \mathrm{nl}$ and $1.7 \mathrm{ng}$ of MO was injected. Animals were raised until $6 \mathrm{dpf}$, after which histological analyses were performed as previously described.

Imaging. Laser scanning confocal microscopy was performed using an LSM 510 (Carl Zeiss) upright microscope outfitted with a 40X C-Apochromat water-immersion objective (NA 1.2). LSM 510 software was used for processing images and for the reconstruction of 3D projections before export to Photoshop version 8.0 (Adobe Systems).

In vivo imaging. Phenylthiourea-treated larvae were anesthetized in tricaine $(4 \mathrm{mg} / \mathrm{ml})$ for $3 \mathrm{~min}$ and mounted in $1.5 \%$ low melting point agarose lateral side up in a Fluorodish (World Precision Instruments). LSM 510 confocal microscope was used for imaging individual bipolar cells in live larvae. For each experimental group, a total of nine cells from at least six animals was imaged, and the parameters of their dendritic arbors were measured using the LSM 510 software. Following the in vivo imaging session, larvae were freed from the agarose for genotyping by DNA amplification and sequencing.

OKR assay. The OKR was performed for larvae at $6 \mathrm{dpf}$ immobilized in $3 \%$ methyl-cellulose and under white light as described previously (Brockerhoff et al., 1995; Stearns et al., 2007). Larvae showing smooth pursuit and saccade eye movements in the direction of the rotating stripes were identified as "responders" and those lacking the response were classified as "nonresponders."

Adult fish (WT $n=8$; $p d e 6 c^{w 59} n=4$ ) were dark adapted for $20 \mathrm{~min}$ before conducting the behavioral assay under dim light conditions (5 lux, measured using a digital light meter; Fisher Scientific S90198) to limit photobleaching of rhodopsin. Alternatively, fish were light adapted for $20 \mathrm{~min}$ (>200 lux ) and the assay was conducted under this bright light condition. Adult fish were immobilized similar to Mueller and Neuhauss (2010) with the following modifications. Fish were briefly anesthetized in tricaine, and the body positioned in the center of a C-shaped length of sponge. The fish was held in place by slipping the sponge into the opening of a glass $20 \mathrm{ml}$ vial filled with fish water such that the fish's head and gills protruded from the mouth of the vial. The vial was then submerged into a $9 \mathrm{~cm}$ diameter finger bowl filled with fish water. The bowl was positioned in the center of the OKR drum and the fish were allowed to recover for $2 \mathrm{~min}$. The drum speed was held constant with the stimulus frequency of $0.7 \mathrm{~Hz}$ at which eye velocity closely matches stimulus velocity (gain > 0.8) (Beck et al., 2004). The number of saccades per minute was counted during $1 \mathrm{~min}$ intervals for a total of $6 \mathrm{~min}$ per animal (WT $n=6 ; p d e 6 c^{w 59} n=3$ ).

Light/darkpreference test. The light/dark preference test was performed essentially as described previously (Champagne et al., 2010). The test consisted of four experimental groups: WT $(n=8), \operatorname{pde}^{w 55}(n=4)$, pde6 $c^{w 59} /$ Xops:mCFP ${ }^{q 13}(n=8)$, and optic nerve-transected animals $(n=3)$. For the latter, optic nerve transection was performed bilaterally on otherwise WT animals. Briefly, fish were anesthetized in tricaine and placed under a dissecting microscope for visualization. The eye was gently rotated in its socket to gain access to the optic nerve, which was then severed using scissors. The animals were allowed to recover for $24 \mathrm{~h}$ before conducting the preference test.

The preference task apparatus consisted of a rectangular plastic tank $(22 \mathrm{~cm} \times 12 \mathrm{~cm} \times 6 \mathrm{~cm} ; 1 \times \mathrm{w} \times \mathrm{d}$ to water surface) illuminated from above with diffuse white light ( 5 lux). Half of the tank was shielded from 

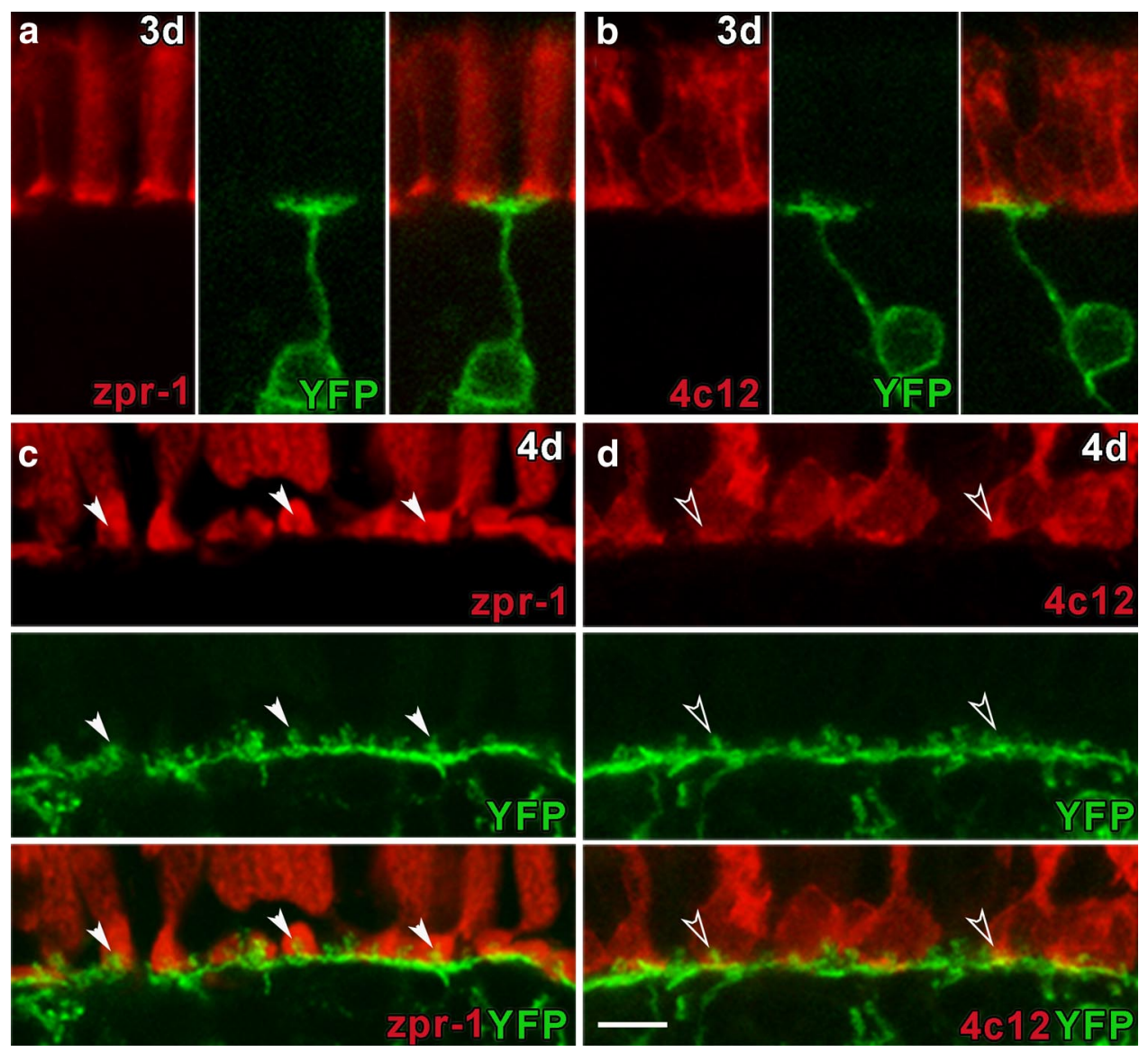

Figure 1. Development of ON bipolar cell contacts with rod and cone photoreceptors. YFP expression by ON bipolar cells (green) at $3 \mathrm{dpf}(\boldsymbol{a}, \boldsymbol{b})$ and $4 \mathrm{dpf}(\boldsymbol{c}, \boldsymbol{d})$, zpr-1 immunolabeling for cones (red; $\boldsymbol{a}, \boldsymbol{c})$, and $4 c 12$ immunolabeling for rods (red; $\boldsymbol{b}, \boldsymbol{d}) \cdot \boldsymbol{a}, \boldsymbol{b}$, At $3 \mathrm{dpf}$, association of the dendritic arbor of individual bipolar cells with cone and rod terminals can be observed. $\boldsymbol{c}$, At 4 dpf, cone-bipolar cell invaginating synapses form lock and key configurations that span the OPL (arrowheads). d, Mixed ON bipolar cell dendrites also contact rod spherules (open arrowheads). Scale bar, $5 \mu \mathrm{m}$.

light with an opaque black lid and darkened walls and bottom. There was no physical barrier between the light and dark compartments and fish were able to swim around freely. Adult fish were dark adapted for $20 \mathrm{~min}$ before conducting the preference test. Each subject was then placed individually in the preference chamber for $\sim 20$ min. Each session consisted of four 5 min trials and the time spent in the light compartment was measured using a stopwatch. The preference test was conducted twice over two distinct days and similar results were obtained on each day. Zone preference was reported as percentage of total time spent in the light compartment. All statistical analyses were performed using PASW Statistics 18.0 (August 2010). One-way ANOVA was conducted on arcsine-transformed data. To account for differences in the number of animals per treatment group, homogeneity of variance was tested using Levene's test and was found to be unequal $(p<0.05)$. Therefore the Welch-Aspin correction was applied to pairwise comparisons to calculate the $F$ critical value. Significance $\left({ }^{*}\right)$ was indicated when $p<0.05$.

Quantification and data analysis of ectopic processes. Data were collected similar to our previous methods (Stearns et al., 2007). For each animal, a single $10-\mu \mathrm{m}$-thick transverse histological section taken through or adjacent to the optic nerve was imaged using the LSM 510 confocal microscope. Using the Zeiss LSM 510 software, a 3D projection of the confocal stack was reconstructed and the bipolar cells from the section of the entire larval eye were examined for quantitative analyses.

Aberrant bipolar cell dendrites are defined as processes extending into the outer nuclear layer (ONL) from the OPL. Their length was measured from the point at which they exit the OPL to their distal end in the ONL. Aberrant axon terminals were defined as ectopic processes extending from the inner plexiform layer (IPL) into the ganglion cell layer (GCL). Their length was measured from the terminal bouton to its tip in the GCL. Data are reported as mean \pm SD per section. Data were collected at
5, 6, 7, and $8 \mathrm{dpf}$. For each time period, $n=4 \mathrm{WT}, 8 p d e 6 c^{w 59}$, and 7-8 Xops:mCFP ${ }^{q 13}$ larvae. One-way ANOVA was conducted. Homogeneity of Variance was tested using Levene's test. A Bonferroni follow-up test was conducted when Levene's test was not significant $(p>0.05)$. When Levene's test was significant $(p<0.05)$, the Welch-Aspin correction was used to calculate the $F$ critical value. Significance ${ }^{*}$ ) was indicated when $p<0.05$.

\section{Results}

To track changes in ON bipolar cell morphology, we took advantage of the nyx:mYFP ${ }^{q 16}$ transgenic zebrafish (Schroeter et al., 2006). Many of the axon terminals of the YFP-expressing bipolar cells are monostratified and terminate in the inner half of the IPL, analogous to rod ON bipolar cells in mammals (Schroeter et al., 2006). In teleosts including zebrafish, the rod ON bipolar cells receive afferent input from rods and cones so are referred to as "mixed ON bipolar cells" (Stell, 1978; Ishida et al., 1980; Marc et al., 1990; Li et al., 2012). Other YFP-expressing cells are bistratified (Schroeter et al., 2006) and the majority would be categorized as cone ON bipolar cells (Li et al., 2012). Synaptic connections in the OPL are first evident at $2 \mathrm{dpf}$ (Schmitt and Dowling, 1999). Variegated expression of the nyx:mYFP ${ }^{16}$ transgene at $3 \mathrm{dpf}$ allows the visualization of individual $\mathrm{ON}$ bipolar cells and their dendritic processes in histological sections and live embryos (Schroeter et al., 2006; Williams et al., 2010). At 3 dpf, ON bipolar cells extend dendrites into the OPL establishing synapses with rod and cone photoreceptors (Fig. $1 a, b$ ). By 4 dpf, YFP expression spreads across the central retina to a large proportion 

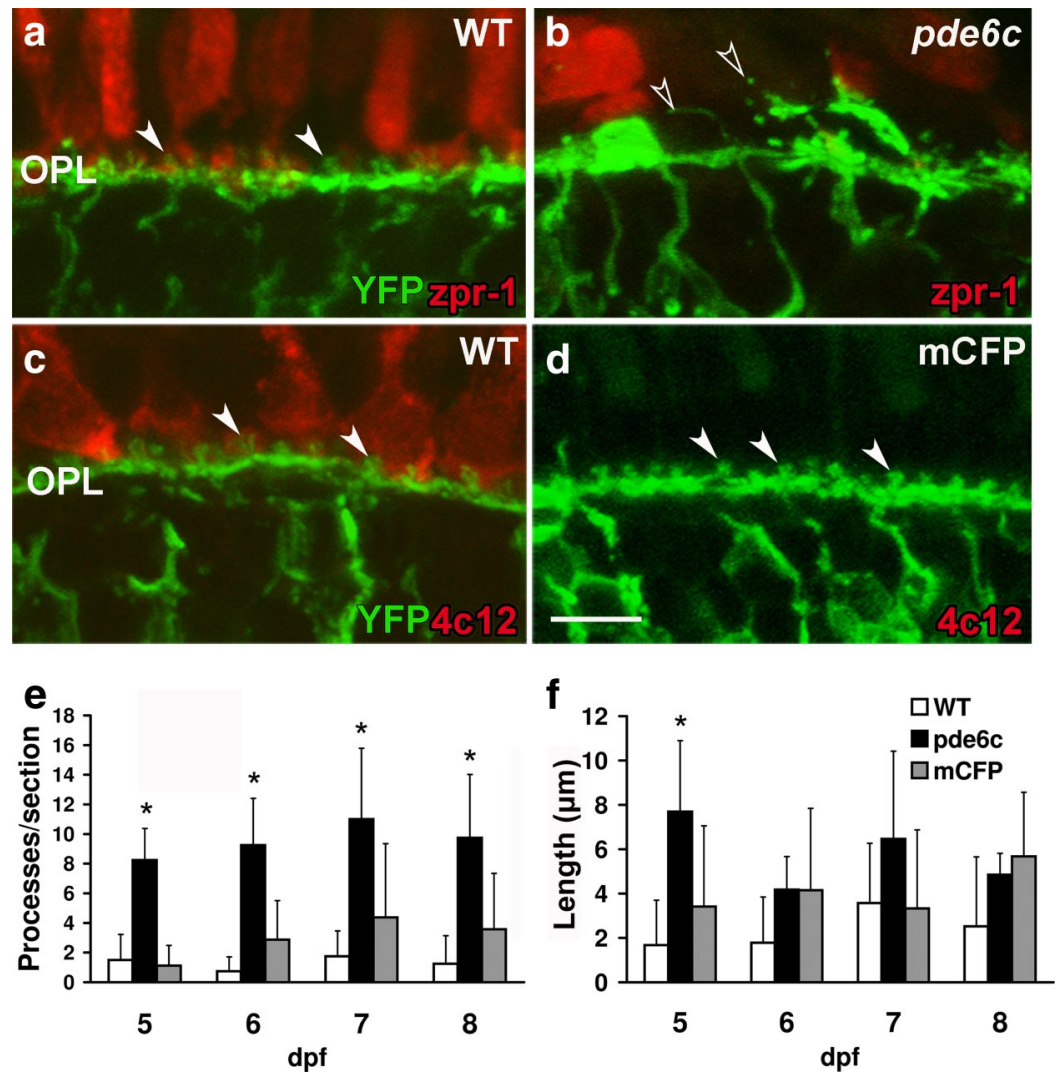

Figure 2. Dendritic remodeling in pde6c $c^{w 59}$ larvae. YFP expression by $0 \mathrm{~N}$ bipolar cells (green) at $6 \mathrm{dpf}(\boldsymbol{a}-\boldsymbol{d}), \mathrm{zpr}-1$ immunolabeling for cones (red; $\boldsymbol{a}, \boldsymbol{b})$, and 4c12 immunolabeling for rods (red; $\boldsymbol{c}, \boldsymbol{d}) . \boldsymbol{a}, \boldsymbol{c}$, The uniform arrangement of cone $(\boldsymbol{a})$ and rod (c) bipolar cell synapses is evident in WT retinas. $\boldsymbol{b}, \mathrm{OPL}$ is remodeled in $p d e 6 c^{w 59}$ retinas. Ectopic dendritic processes project into the ONL (open arrowheads). $\boldsymbol{d}$, OPL organization is not altered with rod loss in Xops:mCFP ${ }^{q 13}$ retinas. $e$, Number of ectopic dendrites per retinal section is significantly greater in $p d e 6 c^{w 59}$ versus WT retinas $5-8 \mathrm{dpf}$. $f$, Length of ectopic dendrites in $p d e 6 c^{w 59}$ retinas is significantly longer than in WT retinas only at $5 \mathrm{dpf}$. WT $(n=4), \operatorname{pde}^{\text {w59 }}(n=8), \mathrm{Xops}^{\mathrm{mCFP}}{ }^{q 13}(n=7-8) .{ }^{*} p<0.05 ; \bar{X} \pm$ SD. Scale bar, $5 \mu \mathrm{m}$.

of ON bipolar neurons (Fig. 1c,d). A contiguous fluorescent layer is formed in the OPL that consists of collections of dendrites that converge to form knob-like protrusions at invaginating synapses with cone pedicles (Fig. $1 c$, arrowheads) and rod spherules (Fig. $1 d$, open arrowheads). The signal intensity and cellular detail revealed in the $n y x: \mathrm{mYFP}^{q 16}$ transgenic line offer a robust method to track the morphology of bipolar cells following photoreceptor cell degenerations.

\section{Cone degeneration in $p d e 6 c^{w 59}$ mutants leads to ON bipolar cell remodeling}

To determine the role that each photoreceptor cell type has in maintaining proper bipolar cell morphology, the nyx:mYFP ${ }^{q 16}$ transgene was bred onto the $p d e 6 c^{w 59}$ and Xops:mCFP ${ }^{q 13}$ photoreceptor degeneration lines. In the central retina of larvae, cones outnumber rods by $20: 1$ providing a model to investigate conedependent changes in retinal structure. In histological sections of 5-8 dpf WT larvae, the dendritic processes of ON bipolar cells are organized into a single lamina with the knob-like protrusions clearly invaginating the photoreceptor terminals (Fig. 2a,c). Significantly expanding our earlier findings (Stearns et al., 2007), cone loss in $p d e 6 c^{w 59}$ retinas results in significant remodeling of ON bipolar cells at all ages tested. Specifically, the fluorescence reveals thickening of regions of the OPL, gaps in other areas, and bipolar cell dendrites lacking the knob-like protrusions of WT retinas. Rather, long ectopic dendritic processes are frequently observed extending into the ONL (Fig. 2b, open arrowheads). Quantifying these changes reveals that these ectopic projections in cone degeneration mutants are more numerous than in WT counterparts at all ages tested ( $5 \mathrm{dpf}, p<0.001 ; 6 \mathrm{dpf}$, $p<0.001 ; 7$ dpf, $p<0.005$; $8 \mathrm{dpf}, p<$ $0.01)$ and at $5 \mathrm{dpf}$ are significantly longer than those observed in WT larvae $(p<$ 0.01 ) (Fig. 2e,f).

In contrast, despite the early onset and near complete loss of rods in Xops: $\mathrm{mCFP}^{q 13}$ transgenic line, the OPL organization in larvae (compare Fig. $2 c, d$ ) and 3-week-old juvenile fish (data not shown) is comparable to that of WT animals. YFP fluorescence demonstrates that the number and length of ectopic dendrites in retinal sections of Xops: $\mathrm{mCFP}^{q 13}$ transgenics are not significantly different from those observed in WT retinas (Fig. 2e,f). In fact, the knob-like protrusions appear to have a more regular spacing and morphology consistent with the precise arrangement of cone terminals (Li et al., 2009) and an absence of projections to the less precisely arranged rod terminals (Fadool, 2003).

We took advantage of the progression of neural differentiation from central to peripheral regions of the retina to look for the earliest signs of degeneration-induced remodeling in live animals. In lateral views of the zebrafish eye, individual ON bipolar neurons expressing YFP could be discerned along their entire length including the full width of their dendritic arbor. At the onset of photoreceptor degeneration at $4 \mathrm{dpf}$, no significant differences are observed in dendritic arbor width between WT $(\bar{X}=7.32 \pm 1.41 \mu \mathrm{m}), \operatorname{pde}^{\text {w5 }} c^{\text {59 }}(\bar{X}=$ $9.02 \pm 1.35 \mu \mathrm{m})$, and Xops:mCFP ${ }^{q 13}$ larvae $(\bar{X}=8.63 \pm 1.63$ $\mu \mathrm{m})(n=9$ bipolar cells per experimental group; $p>0.05)$. However, in $p d e 6 c^{w 59}$ mutant larvae, lengthy ectopic processes extend from dendrites into the ONL $(\bar{X}=10.39 \pm 0.841 \mu \mathrm{m})$, consistent with the dendritic remodeling observed in histological sections from 5 to $8 \mathrm{dpf} p d e 6 c^{w 59}$ larvae. These data suggest that the remodeling is an early consequence of cone loss similar to that observed following rod death in the $r d 1$ mouse.

To determine the extent of cone degeneration-induced alterations, the morphology of bipolar cell axon terminals in the IPL was examined. In WT retinas, mixed ON bipolar cell axon terminals stratify in the inner half of the IPL (Connaughton et al., 2004; Schroeter et al., 2006; Li et al., 2012). Comparison of YFP expression in histological sections of WT and photoreceptor degenerating retinas shows that in $p d e 6 c^{w 59}$ larvae, numerous processes extend into the GCL (Fig. $3 c$, $d$, arrowheads). These ectopic processes are significantly greater in number at all larval days examined (5 dpf, $p<0.001 ; 6 \mathrm{dpf}, p<0.001 ; 7 \mathrm{dpf}, p<0.005 ; 8 \mathrm{dpf}$, $p<0.001$ ) (Fig. $3 g$ ) and their average length is significantly longer than processes observed in WT retinas at $8 \mathrm{dpf}(p<0.005)$ (Fig. $3 h)$. Collateral processes extending horizontally were not observed. Ectopic processes are not observed in Xops:mCFP ${ }^{q 13}$ retinas and the IPL is indistinguishable from that of WT larvae (Fig. $3 e, f)$. These data indicate that degeneration of cones, but not of 
rods, elicits significant remodeling of bipolar cell dendrites and terminals similar to that observed following rod degeneration in mammalian models.

\section{Postsynaptic glutamate receptor} expression is altered in $p d e 6 c^{w 59}$ larvae In addition to ON bipolar cells, rods and cones synapse with OFF bipolar cells and horizontal cells. Changes in postsynaptic processes of OFF bipolar cells and horizontal cells are, respectively, identified using antibodies against GluR4 (Schultz et al., 1997; Yazulla and Studholme, 1999, 2001) and against GluR2 (Klooster et al., 2001; Yazulla and Studholme, 2001; Klooster et al., 2009). In WT retinas, GluR4 labeling is distributed across the OPL (Fig. 4a) lateral to the proximal portion of the YFP-expressing ON bipolar processes (Fig. $4 a$, inset). GluR2 immunolabeling on horizontal cell processes form rosette-like clusters that surround the distal tips of YFP-expressing ON bipolar dendrites (Fig. $4 d$, inset). These are consistent with previous immunoelectron microscopy data that show OFF bipolar dendrites and horizontal cell dendrites flanking ON bipolar cell processes within the invaginating synapse in zebrafish (Klooster et al., 2009). Cone photoreceptor death in the $p d e 6 c^{w 59}$ larvae is associated with a downregulation of GluR4 (Fig. 4b) and GluR2 (Fig. 4e) labeling in the OPL; however, GluR4 and GluR2 puncta flank the few remaining YFP-positive dendritic processes. Labeling of horizontal cell bodies with an anti-GAD antibody confirms the preservation of horizontal cells in pde6c $c^{w 59}$ larvae (data not shown), despite the significant downregulation of dendritic GluR2 labeling. Rod death in Xops: $\mathrm{mCFP}^{q 13}$ larvae results in no loss of labeling or remodeling of either type of postsynaptic glutamate receptor (Fig. $4 c, f$ ).

\section{Synaptic structure is maintained in}

Xops:mCFP ${ }^{q 13}$ and $p d e 6 c^{w 59}$ adults

To address the hypothesis that the anomalous processes observed in the larval retina are in fact due to the loss of the vast majority of the afferents and not the specific loss of cones, we surveyed OPL structure in $p d e 6 c^{w 59}$ adults. As fish grow, new neurons including photoreceptor cells are added at the retinal margin by a population of mitotic progenitor cells located within the circumferential marginal zone (CMZ). At the CMZ in adult zebrafish, rods and cones are generated in approximately equal numbers (Fadool, 2003). In addition, new rods are added in the central retina by a population of mitotic rod progenitors located in the ONL (Raymond and Rivlin, 1987; Otteson and Hitchcock, 2003; Morris et al., 2008b). We have previously demonstrated that in $p d e 6 c^{w 59}$ adults, rods generated near
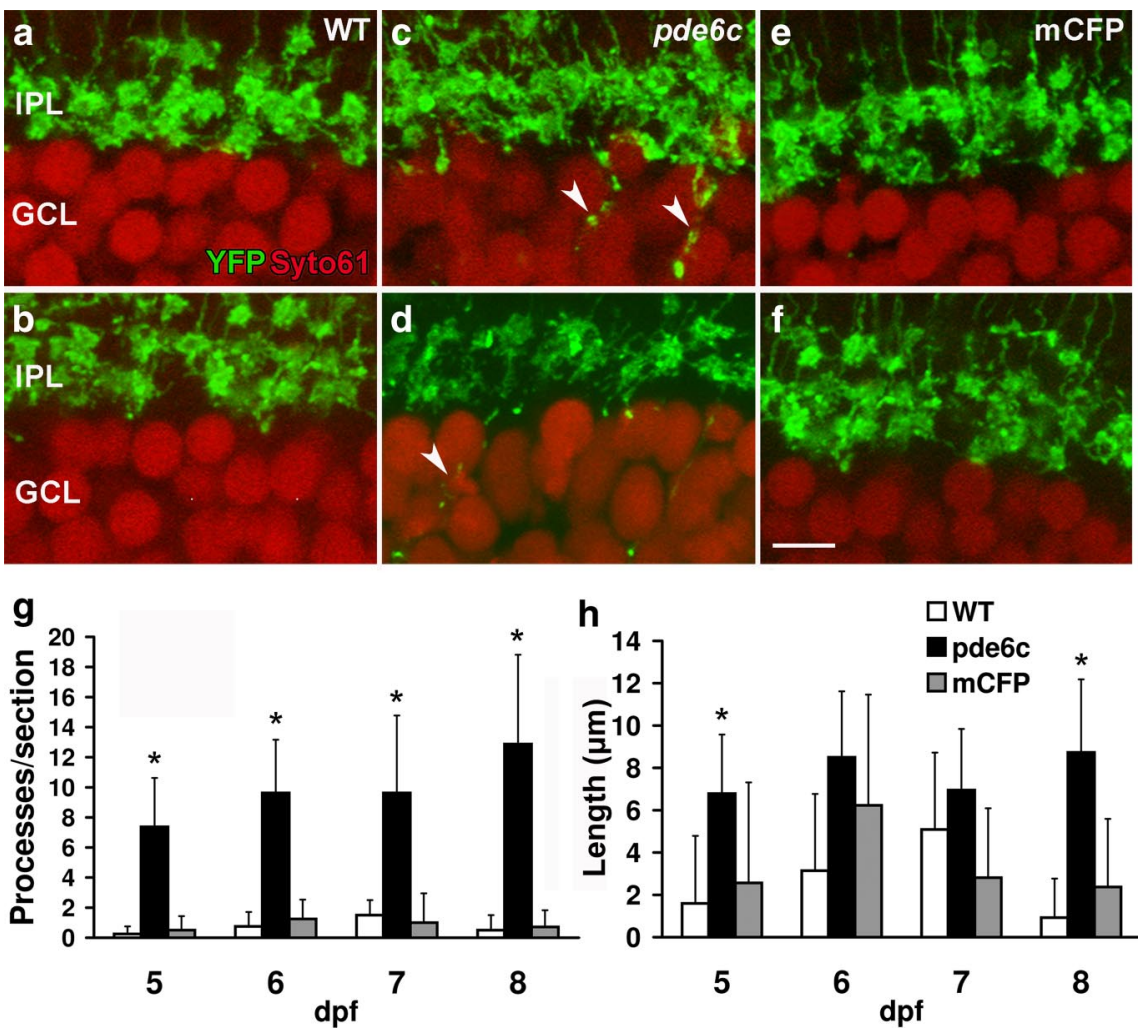

Figure 3. Aberrant axon projections in $p d e 6 c^{w 59}$ larval retinas. YFP expression by $0 \mathrm{~N}$ bipolar cell axons (green; $\boldsymbol{a}-\boldsymbol{f}$ ) and Syto61 nuclear labeling of the GCL (red; $\boldsymbol{a}-\boldsymbol{f})$. WT $(\boldsymbol{a}, \boldsymbol{b})$ and $\operatorname{Xops}_{\mathrm{mCFP}} \mathrm{mCl}^{13}(\boldsymbol{e}, \boldsymbol{f})$ retinas maintain well defined IPL lamination at $6(\boldsymbol{a}, \boldsymbol{e})$ and $8(\boldsymbol{b}, \boldsymbol{f})$ dpf. $\boldsymbol{c}, \boldsymbol{d}$, Axon terminals of $p d e 6{ }^{\mathrm{w}}{ }^{\mathrm{w5}}$ retinas extend ectopic processes into the GCL (arrowheads) shown here at 6 and $8 \mathrm{dpf}$, respectively. $\boldsymbol{g}$, Number of ectopic axonal processes per retinal section is significantly greater in $p d e 6 c^{w 59}$ versus WT retinas consistently through 5-8 dpf. No significant difference is obtained between Xops:mCFP ${ }^{13}$ and WT ectopic processes. $\boldsymbol{h}$, Ectopic processes in $p d e 6 c^{W 59}$ retinas are significantly longer than those in WT retinas at $8 \mathrm{dpf}$. No differences are detected between WT and Xops:mCFP973 retinas. WT $(n=4), \operatorname{pde}^{\text {w59 }}(n=8)$, Xops:mCFP ${ }^{973}(n=7-8) .{ }^{*} p<0.05 ; \overline{\boldsymbol{X}} \pm$ SD. Scale bar, $5 \mu \mathrm{m}$.
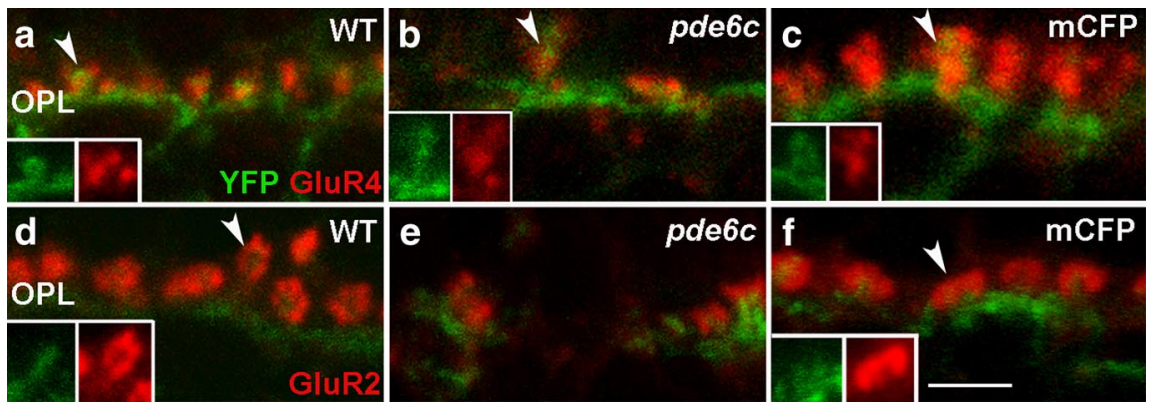

Figure 4. Altered glutamate receptor distribution in larval $p d e 6 c^{w 59}$ retinas. Merged images of YFP expression by ON bipolar cells (green; $\boldsymbol{a}-\boldsymbol{f}$ ), GluR4 immunolabeling on OFF bipolar cells (red; $\boldsymbol{a}-\boldsymbol{c}$ ), and GluR2 labeling on horizontal cell dendrites (red; $\boldsymbol{d}-\boldsymbol{f}$ ). $\boldsymbol{a}$, GluR4 puncta cluster at the proximal portions of ON bipolar cell processes in the WT OPL (arrowhead) and their distribution is disrupted and decreased in pde6 $c^{w 59}$ retinas (b). $\boldsymbol{c}$, Rod loss elicits no change in GluR4 labeling (arrowhead). $\boldsymbol{d}$, In WT larvae, GluR2 immunolabeling appears as rosettes distal to the bipolar cell process (arrowhead). e, pde6 ${ }^{w 59}$ retinas display decreased amounts of rosettes and gaps in immunolabeling. $f, X o p s: m C F^{q 13}$ shows uniformly distributed rosettes throughout the OPL comparable to the WT GluR2 distribution (arrowhead). Insets show individual labels. Scale bar, $2 \mu \mathrm{m}$.

the retinal margin survive in the absence of cones and granulation by rod progenitors slowly fills the central retina. This provided a model to ask whether cone degeneration-induced remodeling is altered by the presence of large numbers of rods in $p d e 6 c^{w 59}$ adults.

Reporter gene expression in adults displays variegated expression allowing imaging of small clusters or of individual bipolar cells. The dendritic processes of mixed ON bipolar cells in the WT 


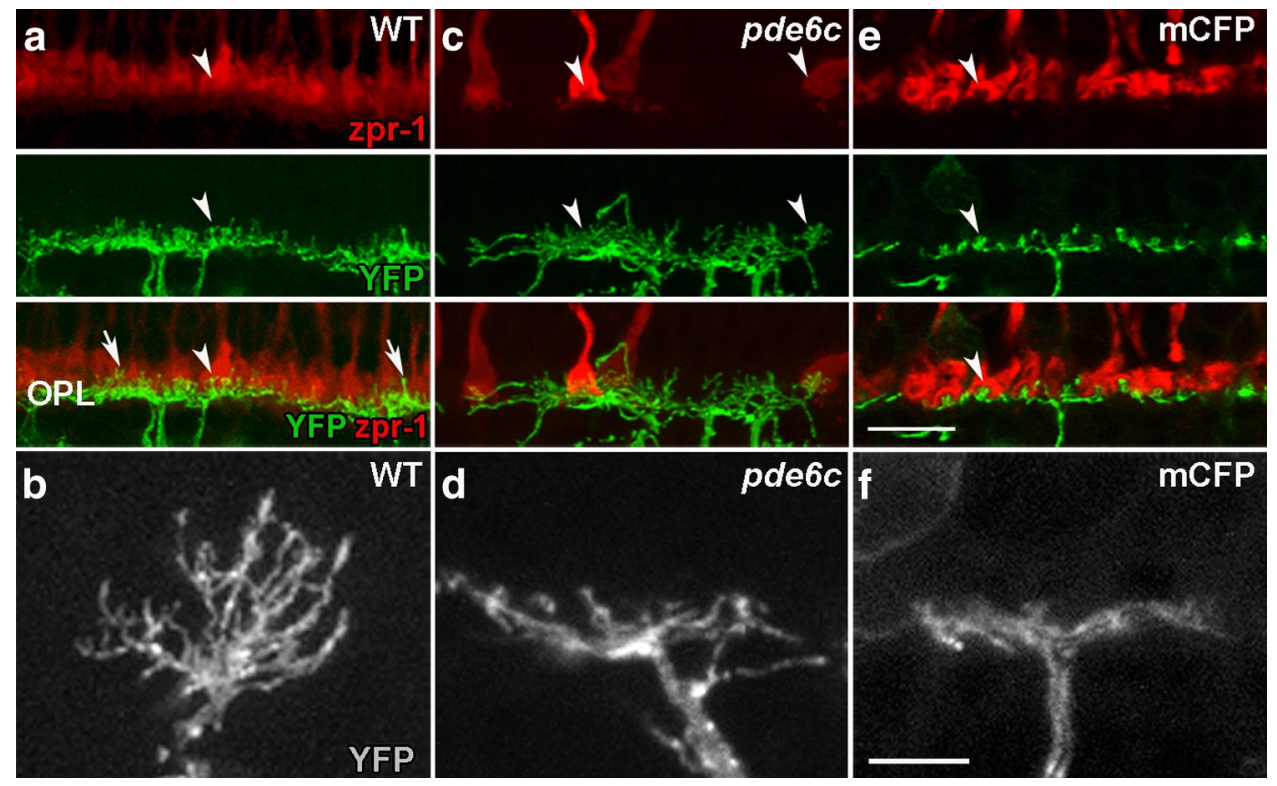

Figure 5. Preservation of photoreceptor-bipolar cell synapses in the $p d e 6 c^{\text {w59 }}$ and Xops:mCFP $q 13$ adults. YFP expression by mixed 0N bipolar cells (green; $\boldsymbol{a}, \boldsymbol{c}, \boldsymbol{e} ;$ gray; $\boldsymbol{b}, \boldsymbol{d}, \boldsymbol{f}$ ) and zpr-1 immunolabeling of cones (red; $\boldsymbol{a}, \boldsymbol{c}, \boldsymbol{e})$. $\boldsymbol{a}$, In WT retinas, YFP expression and zpr-1-labeled cones form contacts (arrowhead). $\boldsymbol{b}$, Image of dendritic arbor of an individual bipolar cell with longer dendrites that putatively contact rod photoreceptors (a, arrows) resulting in a bushy appearance. $c$, Cone-0 bipolar cell invaginating synapses are maintained in pde6 ${ }^{\text {w59 }}$ retinas (arrowheads) and arbors exhibit a bushy appearance. $\boldsymbol{d}$, Individual arbor from a $p d e 6 c^{w 59}$ retina showing preservation of dendritic processes as well as collateral processes. $\boldsymbol{e}, 0 \mathrm{~N}$ bipolar dendritic knobs invaginate cone pedicles throughout the Xops:mCFPq13 OPL (arrowhead). $\boldsymbol{f}$, Loss of rod-bipolar synapses confines branching of the Xops:mCFP ${ }^{q 13}$ ON bipolar dendritic tree. Scale bars: (in $\boldsymbol{e}$ ) $\boldsymbol{a}, \boldsymbol{c}, \boldsymbol{e}, 10 \mu \mathrm{m}$; (in $\boldsymbol{f}$ ) $\boldsymbol{b}$, d, $\boldsymbol{f}, 5 \mu \mathrm{m}$.

adult retina invaginate the cone pedicle (Fig. $5 a$, arrowhead) similar to what is seen in the larval retina, but changes reflecting the increased density of rod photoreceptors are observed. Numerous ON bipolar dendrites extend distally beyond the cone pedicles (Fig. $5 a$, arrows) to contact rod spherules, rendering a bushy appearance to the dendritic lamina and obscuring many of the knob-like processes (Fig. 5a). Imaging of individual cells reveals the numerous long, thin processes that project a considerable depth into the OPL where the rod synapses would terminate (Fig. $5 b)$. The most striking feature of the ON bipolar cells in the $p d e 6 c^{w 59}$ adults is that their structures are largely preserved (Fig. $5 c$ ). Collectively, the dendritic arbors of the ON bipolar cells retain a bushy appearance (Fig. $5 c$ ), consistent with the preservation of the rod synapses, although some sprouting is observed. A few invaginating synapses are still evident between $\mathrm{ON}$ bipolar cells and the sporadic cone pedicles (Fig. $5 c$, arrowheads). Imaging of dendrites of individual bipolar cells in $p d e 6 c^{w 59}$ mutant retinas reveals considerable variation in the number and length of processes observed (Fig. $5 d$ ). The example in Figure $5 d$ highlights the collateral processes frequently observed in the outer retina. In the inner retina, axon terminals do not project into the GCL (data not shown); however, collateral processes extending horizontally at the level of the INL were observed in some samples. In contrast, in Xops:mCFP ${ }^{q 13}$ adult retinas, the bushy appearance of the dendrites of ON bipolar cells is replaced by a very regular arrangement of knob-like processes similar to that observed in the cone-dominated larval retina (Fig. 5e). Despite persistent rod death (Morris et al., 2005) and the lack of rod-bipolar cell synapses, cone-bipolar cell invaginating synapses are preserved throughout the OPL (Fig. $5 e$, arrowhead). Imaging of individual bipolar cell arbors better demonstrates the "more refined" arbor in the Xops:mCFP ${ }^{q 13}$ compared with those of WT or $p d e 6 c^{w 59}$ bipolar cells (Fig. $5 f$ ). No collateral processes were evident in the Xops:mCFP ${ }^{q 13}$ inner retina.
We extend the analysis to include horizontal cell processes by immunolabeling for GluR2 in conjunction with Ribeye-b to visualize rod and cone terminals. In the OPL of WT retinas, GluR2 immunolabeling localizes to small $1 \mu \mathrm{m}$ puncta that are present either isolated (Fig. $6 a$, arrowheads) or arranged into larger, 2-3 $\mu \mathrm{m}$ diameter rosette-like structures (Fig. $6 a$, arrows). The Ribeye-b antiserum displays labeling of both rod and cone terminals in the zebrafish (Williams et al., 2010). Colabeling shows that the GluR2 rosettes localize with cone pedicles (Fig. $6 a$, arrows), while isolated puncta localize with smaller dense structures of rod spherules (Fig. $6 a$, arrowheads). Consistent with this interpretation, the loss of cones in the $p d e 6 c^{w 59}$ retina results in the OPL consisting almost exclusively of the smaller rod-horizontal cell synapses (Fig. 6b, arrowheads). The few remaining rosette complexes are sporadically distributed. Conversely, the Xops: $\mathrm{mCFP}^{q 13}$ OPL is comprised solely of rosette complexes (Fig. $6 c$, arrow) and lacks the punctate synapses associated with rod spherules, indicating that horizontal cell dendrites maintain synaptic connections with cone photoreceptors in the absence of rods. Together, the ON bipolar cell morphology and colabeling for GluR2 and Ribeye-b demonstrate that the neural connectivity within the OPL remains largely intact following rod or cone degeneration and supports the hypothesis that the significant remodeling observed in homozygous $p d e 6 c^{w 59}$ larvae stems from the loss of the majority of the presynaptic input and not the selective death of the cone photoreceptors.

\section{Visual responses are preserved in $p d e 6 c^{w 59}$ mutant adults}

Our previously published results and data reported here demonstrate that $p d e 6 c^{w 59}$ mutant larvae, in addition to showing loss of cone function and rod dystrophy (Stearns et al., 2007), display significant remodeling of second-order neurons reported above. In $p d e 6 c^{w 59}$ mutant juveniles, observation of a very small a-wave component in the rod electroretinogram (ERG) and no b-wave 
suggests that rod function continues to be compromised (Stearns et al., 2007). However, in the $p d e 6 c^{w 59}$ adults, rod survival and evidence of intact synapses between rods and second-order neurons (Fig. 6) prompted us to test if visual function has been gained, i.e., can homozygous $p d e 6 c^{\text {w59 }}$ adults respond to visual stimuli? To address this question, WT and homozygous $p d e 6 c^{w 59}$ adults and two models of blindness (optic nerve-transected animals and $p d e 6 c^{w 59} / X o p s: \mathrm{mCFP}^{q 13}$ fish demonstrating rod and cone degeneration) were tested for light/dark preference and for the presence of a scotopic OKR. The light/dark preference test is most frequently used as a measure of anxiety, and although it does not provide information on visual acuity, unstressed adult zebrafish display a robust and quantitative preference for the light side of a chamber (Gerlai et al., 2000; Champagne et al., 2010). Consistent with published results, the WT adult zebrafish spend significantly more time in the brighter compartment of the light/dark apparatus when compared with optic nerve-transected animals $(p<0.001)$ or $p d e 6 c^{w 59} /$ Xops:mCFP ${ }^{q 13}$ animals $(p<0.001)$ (Fig. 7$)$. Both the genetic and surgical lesion models of blindness show no preference for the light or dark compartments, validating that the responses are dependent upon photoreceptor function and not the intrinsically photosensitive ganglion cells or similar melanopsin-expressing cells (Schmidt et al., 2011). More remarkably, dark-adapted homozygous $p d e 6 c^{w 59}$ adults spend significantly more time in the bright side of the apparatus. In repeated trials, $p d e 6 c^{w 59}$ adult preference for the lit compartment did not significantly differ from WT adults $(p>0.05)$ but was significantly greater than those of the blind fish (optic nerve-transected, $p<0.05 ; p d e 6 c^{w 59} /$ Xops: $\left.\mathrm{mCFP}^{q 13}, p<0.05\right)$. All WT and $p d e 6 c^{w 59}$ adults were subsequently tested for an OKR. Both groups when dark adapted displayed a robust OKR, however, the average number of saccades per minute for $p d e 6 c^{w 59}$ adults was approximately twothirds of that observed for the WT fish. The saccade-like movements of light-adapted $p d e 6 c^{w 59}$ adults were no different from spontaneous eye movements. These data indicate that photoreceptor function is gained in animals that as larvae displayed no visually evoked behavior.

Increased rod number protects the larval retina from cone degeneration-induced remodeling

We next asked if these findings from adults could be extended to larval fish. Would an increase in the number of rod photoreceptors in the $p d e 6 c^{w 59}$ mutant larvae protect the retina from degenerationinduced remodeling? To test this hypothesis we took advantage of genetic methods to manipulate the number and density of rod photoreceptors in the larva. In a third generation screen for alterations in rod photoreceptor patterning and survival, we isolated mutations in two loci that regulated rod cell number. The first of these, lots-of-rods (lor $\left./ t b \times 2 b^{p 25 b b t l}\right)$, results in a cell-fate switch of SWS1 cones into rod photoreceptors (Alvarez-Delfin et al., 2009). The second, lor junior (lir), mapped to an interval on chromosome 7 that includes the sine oculus homolog six7 (K. Alvarez-Delfin and J.M. Fadool, unpublished observations). Injection of a previously pub-

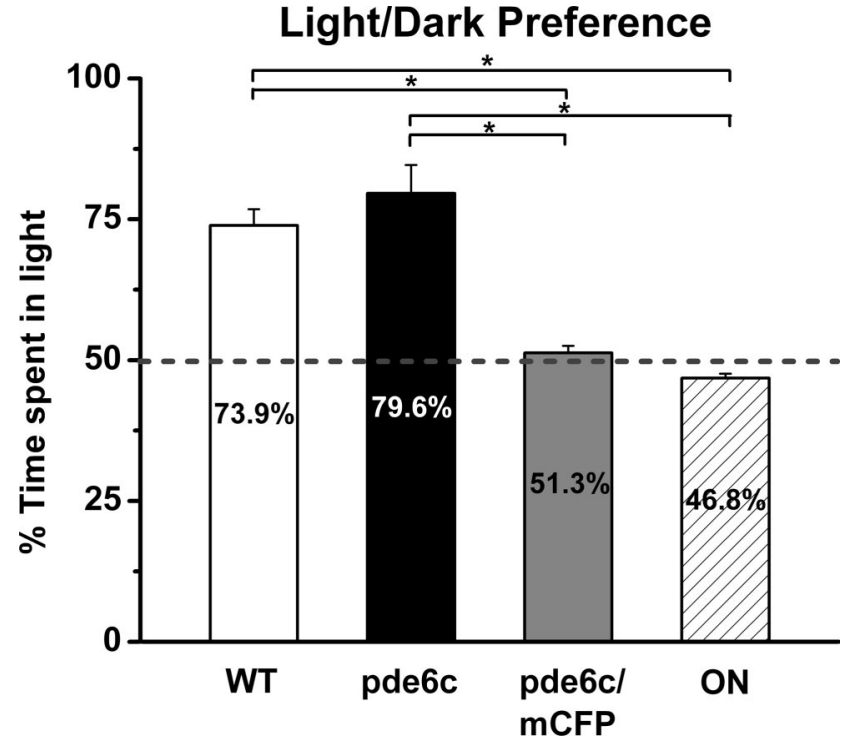

Figure 7. Preservation of visual responses in $p d e 6 c^{w 59}$ adults. WT and $p d e 6 c^{w 59}$ adults show robust phototaxis (73.9 and 79.6\%, respectively). Adults exhibiting rod and cone degeneration ( pde6 $^{\text {w59 }}{ }^{\text {Xops:mCFP }}{ }^{913}, 51.3 \%$ ) or following optic nerve transection (ON, 46.8\%) show no preference. Light preferences of the WT and $p d e 6 c^{w 59}$ groups do not significantly differ from one

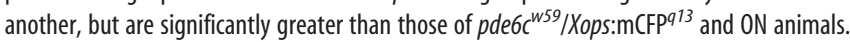
Shown are the data for one of the two trial days. WT $(n=8), p d e 6 c^{w 59}(n=4), p d e 6 c^{w 59} / X_{o p s}$ : $\mathrm{mCFP}{ }^{13}(n=8), 0 \mathrm{~N}(n=3) .{ }^{*} p<0.05 ; \bar{X} \pm$ SEM.

lished translation-blocking MO to six7 (Inbal et al., 2007) phenocopies the lir mutation in a dosage-dependent manner. Either method increases the number of rod photoreceptors approximately fourfold, or approximately equal to $20-25 \%$ of the total cone complement. To increase the number of rods in $p d e 6 c^{w 59}$ mutant larvae, we placed the lor/tbx $2 b^{p 25 b b t l}$ allele on the $p d e 6 c^{w 59} / n y x: \mathrm{mYFP}^{q 16}$ background or used MO knockdown of six7.

The lor $/ t b \times 2 b^{p 25 b b t l}$ allele or six7 MO injections on the WT background significantly increase the number of rod photorecep- 

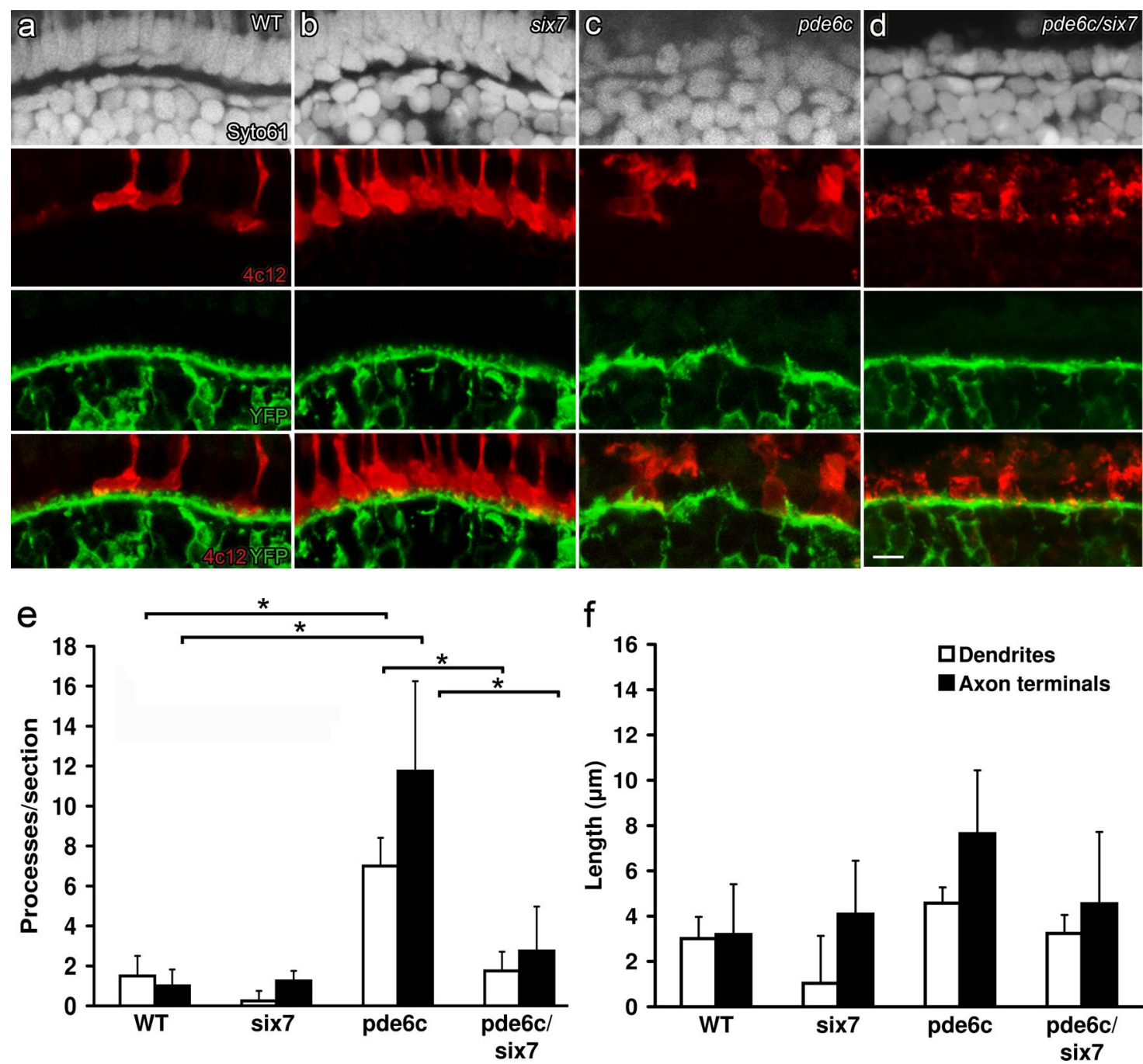

Figure 8. Protection of mixed ON bipolar morphology in $p d e 6 c^{w 59} /$ six7-MO larvae. Syto61 nuclear label (gray), $4 c 12$ immunolabeling for rods (red), and YFP expression by 0N bipolar cells (green). $\boldsymbol{a}$, Syto61 labeling in WT larvae shows the lamination of the outer retina. Few rods are present in the WT central retina, and YFP distribution highlights the continuous OPL and knob-like processes. $\boldsymbol{b}$, Rod photoreceptor cell number is increased but laminar organization is maintained in six 7 morphants. c, ONL is lost and lamination is disrupted in pde6 ${ }^{w 59}$ larvae; the remaining rods are

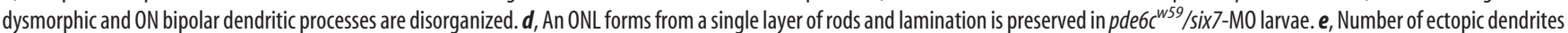
(white bars) $(p<0.001)$ and ectopic axon terminal processes (black bars) $(p<0.001)$ is significantly different between WT and $p d e 6 c^{w 59}$ retinas. The number of ectopic processes is significantly

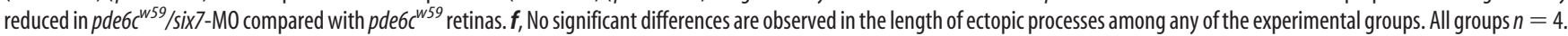
${ }^{*} p<0.05 ; \bar{X} \pm$ SD. Scale bar, $5 \mu \mathrm{m}$.

tors in the ONL (Fig. $8 a, b$ ). In histological sections, the additional rod cell bodies form a single row in the ONL proximal to the numerous cones (compare Syto61 nuclear labeling and $4 \mathrm{c} 12 \mathrm{im}$ munoreactivity in Fig. $8 a, b$ ). In $p d e 6 c^{w 59}$ mutants, the ONL is in disarray with few surviving cells, and the OPL is disorganized (Syto61 staining and YFP expression in Fig. 8c). The increase in the number of rod photoreceptors in the $p d e 6 c^{w 59} /$ six 7 -MO cone degeneration model results in a single row of photoreceptors in the ONL that label for markers of rod photoreceptors (Fig. $8 d$ ). The OPL lacks the hallmarks of cone degeneration-induced remodeling; ON bipolar dendrites are confined to a contiguous OPL with significantly fewer ectopic processes than the $p d e 6 c^{w 59}$ mutants alone $(p<0.001)$ (Fig. $8 d$,e, white bars). The OPL, however, lacks the knob-like structures that typically invaginate cone pedicles. ON bipolar axon terminals in these $p d e 6 c^{w 59} /$ six $7-\mathrm{MO}$ retinas terminate appropriately in the IPL and we do not observe processes extending into the GCL $(p<0.001)$ (Fig. 8e, black bars). These retinas also demonstrate a slight increase in photoreceptor-horizontal cell synap- tic complexes when compared with $p d e 6 c^{w 59}$ retinas, consistent with the overall increase in the total number of photoreceptors (data not shown). The OPL exhibits an increase in GluR2 puncta and in Ribeye-b/GluR2 colocalization compared with $p d e 6 c^{w 59}$ mutants alone, though these synaptic complexes are not as abundant as in WT retinas. Together, the data from the larvae and adult suggest that remodeling can be prevented or significantly reduced by a small fraction of the original number of photoreceptors.

\section{Discussion}

Our study took advantage of the rod- and cone-specific degeneration in zebrafish and the ability to genetically manipulate rod number and distribution to provide answers for two specific questions. First, is remodeling a common consequence of photoreceptor degeneration in vertebrates? Second, can a small number of surviving photoreceptors protect against the degeneration-induced alterations? 
Data from mammalian models and reported here unequivocally demonstrate that the degree of the neural remodeling is a consequence of the severity of photoreceptor cell loss. Rods account for $\sim 95 \%$ of photoreceptors in the mouse retina and the peripheral human retina. In the larval zebrafish, cones account for $\sim 95 \%$ of photoreceptors in the central retina. The $p d e 6 c^{w 59}$ mutation in zebrafish directly affects the vast majority of photoreceptors and secondarily induces dendrite remodeling and alterations in receptor labeling mirroring mouse models of RP (Strettoi and Pignatelli, 2000; Strettoi et al., 2002, 2003; Gargini et al., 2007). Slow onset degeneration of rods in the $r d 10$ mouse, another spontaneous mutation in pde6b, and in the $\mathrm{P} 23 \mathrm{H}$ rhodopsin rat model display slower progression of secondary alterations (Cuenca et al., 2004; Phillips et al., 2010). Similarity is also noted to the small but significant number of aberrant bipolar cell processes in the inner retina of larval zebrafish (Fig. 3). Zebrafish bipolar terminals display exploratory behavior up to $10 \mathrm{dpf}$ (Schroeter et al., 2006), so it is conceivable that the loss of presynaptic input influences the ability of cells to refine synaptic connections. Rod bipolar and horizontal cell remodeling are common features in mouse models with defective photoreceptor ribbon synapses or impaired synaptic transmission (Chang et al., 2006; Bayley and Morgans, 2007; Specht et al., 2007; Grossman et al., 2009). However, mutations affecting the postsynaptic cell, such as in the nob mouse (Ball et al., 2003) or mGluR6-deficient mouse (Tagawa et al., 1999), are not associated with outer retinal alterations, evidence that remodeling in the vertebrate retina is likely the direct consequence of the degree of severity of presynaptic loss.

The preservation of OPL structures and evidence of visual behavior in $p d e 6 c^{w 59}$ adults was unexpected. The $p d e 6 c^{w 59}$ allele results in the death of nearly all cones in larvae and secondary rod loss with no recordable ERG at least through $21 \mathrm{dpf}$ (Stearns et al., 2007). In addition to the remodeling reported in this study, cone death triggers a robust regeneration response by Muller glia in larvae and adults, precipitating an ensuing cycle of cone genesis and death and reactive gliosis (Morris et al., 2008a). However, the rods of $p d e 6 c^{w 59}$ juveniles and adults survive; form a well defined ONL, and synapse with bipolar and horizontal cells (Fig. 6; Stearns et al., 2007). The presence of a light preference and scotopic OKR demonstrates that the rod pathway is functional in these once blind fish. A hypomorphic allele of the cone phosphodiesterase, $p d e 6 c^{r w 76 a}$, displays a much slower onset of degeneration. Cones are present in the central retina at $8 \mathrm{dpf}$, and secondary death of rods is not reported (Nishiwaki et al., 2008). pde6c $c^{r w 76 a}$ mutants show a near normal time course of development of the rod pathway with an OKR detected at $21 \mathrm{dpf}$ under dim light conditions. Thus, just as cone survival and synaptogenesis are maintained in the absence of rods (Strettoi et al., 2004; Morris et al., 2005; Roger et al., 2012), survival of rods and synaptic connections are independent of cone function.

The lack of demonstrative remodeling in the OPL and presence of visual responses in the $p d e 6 c^{w 59}$ adults prompted us to test if increasing the number of surviving photoreceptors protects against degeneration-induced remodeling. We show, using two independent methods, that an increased number and uniform distribution of rods protect the larval retina from cone degeneration-induced remodeling. SWS1 cones comprise about $20 \%$ of the total photoreceptor cell complement in larval zebrafish retina, and consequently mutations of $t b x 2 b$ result in a similar proportion differentiating as rods (Alvarez-Delfin et al., 2009). The six7 MO produces a similar increase in rod number and distribution but likely from additional mitotic activity of photoreceptor cell precursors. It is well documented that modest declines in photoreceptor number do not elicit a significant alteration in retinal architecture or physiology. However, with continued decline in the number of photoreceptors, gross changes in second-order neuron structure and function ensue. This is consistent with data showing significant ERG alterations only after the ONL thins below 50\% (Machida et al., 2000; Chrysostomou et al., 2009). Sekirnjak et al. (2011) report the loss of light-evoked responses in ganglion cells and spontaneous network oscillations associated with the photoreceptor layer thickness reduced to $\sim 20 \%$ in P23H rhodopsin rat model of RP. Similarly, analysis of human samples by Cideciyan et al. (1998) demonstrated that cone dysfunction arises in retinas only after the loss of at least $75 \%$ of rod outer segments. The protection conferred by survival of as few as $20 \%$ of the original number of photoreceptors in the genetically manipulated larvae provides a model to screen for mechanisms that trigger or protect from the secondary changes associated with photoreceptor degenerations.

Our working hypothesis is that following photoreceptor cell degeneration, plasticity in synapse formation between the second-order neurons with the remaining photoreceptors protects from degeneration-induced remodeling. Afferents play a critical role in the proper spatial distribution of bipolar cell dendritic terminals. The gross morphology of retinal bipolar cells, such as branching and stratification, is regulated cell intrinsically but the fine connectivity of bipolar cell dendritic tips requires the presence of specific photoreceptors (Keeley and Reese, 2010). In an all cone $\mathrm{Nrl}-/-$ mouse retina, rod bipolar cells maintain their normal morphology but form synaptic connections with cones (Strettoi et al., 2004), and in the $\mathrm{Cr} x \mathrm{p}-\mathrm{Nrl}$ mouse, in which cones differentiate as rods, the cone circuitry is recruited by rods (Oh et al., 2007). In photoreceptor degenerations, new synaptic connections are abundant (Marc et al., 2003; Jones et al., 2012); input-deprived rod bipolar cells contact functional cones in Rho-/- mice, and CNGA3-I- mice that lack cone function display cone bipolar cell synapses with rods (Haverkamp et al., 2006). These suggest that rewiring is driven by the presence of an alternative presynaptic target, and synaptic partnering of bipolar cells with photoreceptors is not absolute (Haverkamp et al., 2006). Similar findings also extend to horizontal cells (Raven et al., 2007). Aging in humans and mouse models is also associated with the sprouting of bipolar and horizontal cell processes that form ectopic synapses with photoreceptor terminals that have retracted into the ONL (Liets et al., 2006; Eliasieh et al., 2007; Terzibasi et al., 2009). Based upon our current data for the Xops:mCFP ${ }^{q 13}$ transgenic line, synapses between rod horizontal cells and cones may account for the expanded size and increased labeling for GluR2 at the cone pedicles. We anticipate that cone bipolar and horizontal cells will show similar plasticity in synapse formation with the remaining rods in $p d e 6 c^{w 59}$ zebrafish. Thus in addition to the role photoreceptors play in finetuning postsynaptic cell morphology the mere presence of a significant number of afferents protects from degeneration-induced remodeling.

One limitation of our findings is the lack of a reliable method to unequivocally demonstrate that rod function in $p d e 6 c^{w 59}$ / six7-MO larvae underlies the protection. Rhodopsin is detected in the ventral retina as early as $50 \mathrm{~h}$ postfertilization (hpf), characteristic outer segments and invaginating synapses appear a day later, and by $5 \mathrm{dpf}$, morphologically mature rods are sporadically distributed across the retina (Raymond et al., 1995; Schmitt and Dowling, 1999; Fadool, 2003). The first detectable rod responses by ERG, however, appear between 15 and $21 \mathrm{dpf}$ (Saszik and Bilotta, 1999; Bilotta et al., 2001). In comparison, cone opsins are 
first detected at $50 \mathrm{hpf}$ and cone differentiation spreads across the retina by $4 \mathrm{dpf}$, and robust ERGs and visually evoked behavior with spectral properties attributed to cone function are detectable at $5 \mathrm{dpf}$. Data establish that the OKR is driven largely by red and green cones, while short-wavelength cones contribute to larval phototaxis (Orger and Baier, 2005). But no behavior has been attributed to rod responses in larvae. This is not simply a matter that cones outnumber rods by 20:1 as there is also a lack of evidence of rod-mediated behavioral response or a light-evoked ERG response in lor $/ t b \times 2 b^{p 25 b b t l}$ larvae (Alvarez-Delfin et al., 2009; unpublished observations). Therefore, whether it is glutamate release from the rod synapse or the presence of another factor supplied by photoreceptors that provides the protective effect in larvae necessitates future studies.

The similarities between secondary changes in response to cone death in larval retinas and rod death in mammalian models of RP add to the benefits of the zebrafish as a model of retinal disease but should not overshadow our original premise that the cone-dominated larval retina remains a valuable tool for understanding cone-mediated vision in the human central retina. This study demonstrates the potential benefits of protecting the few remaining photoreceptors from decline or death during progressive photoreceptor degenerations and that our genetic models are potentially useful for the systematic analysis of factors that slow or even prevent the secondary deteriorations associated with neural degenerative disease.

\section{References}

Alvarez-Delfin K, Morris AC, Snelson CD, Gamse JT, Gupta T, Marlow FL, Mullins MC, Burgess HA, Granato M, Fadool JM (2009) Tbx2b is required for ultraviolet photoreceptor cell specification during zebrafish retinal development. Proc Natl Acad Sci U S A 106:2023-2028. CrossRef Medline

Ball SL, Pardue MT, McCall MA, Gregg RG, Peachey NS (2003) Immunohistochemical analysis of the outer plexiform layer in the nob mouse shows no abnormalities. Vis Neurosci 20:267-272. Medline

Bayley PR, Morgans CW (2007) Rod bipolar cells and horizontal cells form displaced synaptic contacts with rods in the outer nuclear layer of the nob2 retina. J Comp Neurol 500:286-298. CrossRef Medline

Beck JC, Gilland E, Tank DW, Baker R (2004) Quantifying the ontogeny of optokinetic and vestibuloocular behaviors in zebrafish, medaka, and goldfish. J Neurophysiol 92:3546-3561. CrossRef Medline

Bernardos RL, Barthel LK, Meyers JR, Raymond PA (2007) Late-stage neuronal progenitors in the retina are radial Muller glia that function as retinal stem cells. J Neurosci 27:7028-7040. CrossRef Medline

Berson EL, Rosner B, Weigel-DiFranco C, Dryja TP, Sandberg MA (2002) Disease progression in patients with dominant retinitis pigmentosa and rhodopsin mutations. Invest Ophthalmol Vis Sci 43:3027-3036. Medline

Bilotta J, Saszik S, Sutherland SE (2001) Rod contributions to the electroretinogram of the dark-adapted developing zebrafish. Dev Dyn 222: 564-570. CrossRef Medline

Breuer DK, Yashar BM, Filippova E, Hiriyanna S, Lyons RH, Mears AJ, Asaye B, Acar C, Vervoort R, Wright AF, Musarella MA, Wheeler P, MacDonald I, Iannaccone A, Birch D, Hoffman DR, Fishman GA, Heckenlively JR, Jacobson SG, Sieving PA, et al. (2002) A comprehensive mutation analysis of RP2 and RPGR in a North American cohort of families with X-linked retinitis pigmentosa. Am J Hum Genet 70:1545-1554. CrossRef Medline

Brockerhoff SE, Hurley JB, Janssen-Bienhold U, Neuhauss SC, Driever W, Dowling JE (1995) A behavioral screen for isolating zebrafish mutants with visual system defects. Proc Natl Acad Sci U S A 92:10545-10549. CrossRef Medline

Champagne DL, Hoefnagels CC, de Kloet RE, Richardson MK (2010) Translating rodent behavioral repertoire to zebrafish (danio rerio): relevance for stress research. Behav Brain Res 214:332-342. CrossRef Medline

Chang B, Heckenlively JR, Bayley PR, Brecha NC, Davisson MT, Hawes NL, Hirano AA, Hurd RE, Ikeda A, Johnson BA, McCall MA, Morgans CW, Nusinowitz S, Peachey NS, Rice DS, Vessey KA, Gregg RG (2006) The nob2 mouse, a null mutation in Cacnalf: anatomical and functional abnormalities in the outer retina and their consequences on ganglion cell visual responses. Vis Neurosci 23:11-24. Medline

Chrysostomou V, Stone J, Valter K (2009) Life history of cones in the rhodopsin-mutant $\mathrm{P} 23 \mathrm{H}-3$ rat: evidence of long-term survival. Invest Ophthalmol Vis Sci 50:2407-2416. CrossRef Medline

Cideciyan AV, Hood DC, Huang Y, Banin E, Li ZY, Stone EM, Milam AH, Jacobson SG (1998) Disease sequence from mutant rhodopsin allele to rod and cone photoreceptor degeneration in man. Proc Natl Acad Sci U S A 95:7103-7108. CrossRef Medline

Connaughton VP, Graham D, Nelson R (2004) Identification and morphological classification of horizontal, bipolar, and amacrine cells within the zebrafish retina. J Comp Neurol 477:371-385. CrossRef Medline

Cuenca N, Pinilla I, Sauv é Y, Lu B, Wang S, Lund RD (2004) Regressive and reactive changes in the connectivity patterns of rod and cone pathways of $\mathrm{P} 23 \mathrm{H}$ transgenic rat retina. Neuroscience 127:301-317. CrossRef Medline

Eliasieh K, Liets LC, Chalupa LM (2007) Cellular reorganization in the human retina during normal aging. Invest Ophthalmol Vis Sci 48: 2824-2830. CrossRef Medline

Fadool JM (2003) Development of a rod photoreceptor mosaic revealed in transgenic zebrafish. Dev Biol 258:277-290. CrossRef Medline

Fadool JM, Brockerhoff SE, Hyatt GA, Dowling JE (1997) Mutations affecting eye morphology in the developing zebrafish (danio rerio). Dev Genet 20:288-295. CrossRef Medline

Fisher SK, Lewis GP (2003) Muller cell and neuronal remodeling in retinal detachment and reattachment and their potential consequences for visual recovery: a review and reconsideration of recent data. Vision Res 43:887897. CrossRef Medline

Gargini C, Terzibasi E, Mazzoni F, Strettoi E (2007) Retinal organization in the retinal degeneration $10(\mathrm{rd} 10)$ mutant mouse: a morphological and ERG study. J Comp Neurol 500:222-238. CrossRef Medline

Gerlai R, Lahav M, Guo S, Rosenthal A (2000) Drinks like a fish: Zebra fish (danio rerio) as a behavior genetic model to study alcohol effects. Pharmacol Biochem Behav 67:773-782. CrossRef Medline

Grossman GH, Pauer GJ, Narendra U, Peachey NS, Hagstrom SA (2009) Early synaptic defects in tulp1-/- mice. Invest Ophthalmol Vis Sci 50: 3074-3083. CrossRef Medline

Haverkamp S, Michalakis S, Claes E, Seeliger MW, Humphries P, Biel M, Feigenspan A (2006) Synaptic plasticity in CNGA3(-/-) mice: cone bipolar cells react on the missing cone input and form ectopic synapses with rods. J Neurosci 26:5248-5255. CrossRef Medline

Inbal A, Kim SH, Shin J, Solnica-Krezel L (2007) Six3 represses nodal activity to establish early brain asymmetry in zebrafish. Neuron 55:407-415. CrossRef Medline

Ishida AT, Stell WK, Lightfoot DO (1980) Rod and cone inputs to bipolar cells in goldfish retina. J Comp Neurol 191:315-335. CrossRef Medline

Jones BW, Kondo M, Terasaki H, Lin Y, McCall M, Marc RE (2012) Retinal remodeling. Jpn J Ophthalmol 56:289-306. CrossRef Medline

Keeley PW, Reese BE (2010) Role of afferents in the differentiation of bipolar cells in the mouse retina. J Neurosci 30:1677-1685. CrossRef Medline

Klooster J, Studholme KM, Yazulla S (2001) Localization of the AMPA subunit GluR2 in the outer plexiform layer of goldfish retina. J Comp Neurol 441:155-167. CrossRef Medline

Klooster J, Yazulla S, Kamermans M (2009) Ultrastructural analysis of the glutamatergic system in the outer plexiform layer of zebrafish retina. J Chem Neuroanat 37:254-265. CrossRef Medline

Lewis A, Williams P, Lawrence O, Wong RO, Brockerhoff SE (2010) Wildtype cone photoreceptors persist despite neighboring mutant cone degeneration. J Neurosci 30:382-389. CrossRef Medline

Lewis GP, Linberg KA, Fisher SK (1998) Neurite outgrowth from bipolar and horizontal cells after experimental retinal detachment. Invest Ophthalmol Vis Sci 39:424-434. Medline

Li L, Dowling JE (1997) A dominant form of inherited retinal degeneration caused by a non-photoreceptor cell-specific mutation. Proc Natl Acad Sci U S A 94:11645-11650. CrossRef Medline

Li YN, Tsujimura T, Kawamura S, Dowling JE (2012) Bipolar cellphotoreceptor connectivity in the zebrafish (danio rerio) retina. J Comp Neurol 520:3786-3802. CrossRef Medline

Li YN, Matsui JI, Dowling JE (2009) Specificity of the horizontal cellphotoreceptor connections in the zebrafish (danio rerio) retina. J Comp Neurol 516:442-453. CrossRef Medline

Liets LC, Eliasieh K, van der List DA, Chalupa LM (2006) Dendrites of rod 
bipolar cells sprout in normal aging retina. Proc Natl Acad Sci U S A 103:12156-12160. CrossRef Medline

Machida S, Kondo M, Jamison JA, Khan NW, Kononen LT, Sugawara T, Bush RA, Sieving PA (2000) P23H rhodopsin transgenic rat: correlation of retinal function with histopathology. Invest Ophthalmol Vis Sci 41:3200 3209. Medline

Malicki J, Neuhauss SC, Schier AF, Solnica-Krezel L, Stemple DL, Stainier DY, Abdelilah S, Zwartkruis F, Rangini Z, Driever W (1996) Mutations affecting development of the zebrafish retina. Development 123:263-273. Medline

Marc RE, Liu WL, Kalloniatis M, Raiguel SF, van Haesendonck E (1990) Patterns of glutamate immunoreactivity in the goldfish retina. J Neurosci 10:4006-4034. Medline

Marc RE, Jones BW, Watt CB, Strettoi E (2003) Neural remodeling in retinal degeneration. Prog Retin Eye Res 22:607-655. CrossRef Medline

Morris AC, Schroeter EH, Bilotta J, Wong RO, Fadool JM (2005) Cone survival despite rod degeneration in XOPS-mCFP transgenic zebrafish. Invest Ophthalmol Vis Sci 46:4762-4771. CrossRef Medline

Morris AC, Scholz TL, Brockerhoff SE, Fadool JM (2008a) Genetic dissection reveals two separate pathways for rod and cone regeneration in the teleost retina. Dev Neurobiol 68:605-619. CrossRef Medline

Morris AC, Scholz T, Fadool JM (2008b) Rod progenitor cells in the mature zebrafish retina. Adv Exp Med Biol 613:361-368. CrossRef Medline

Mueller KP, Neuhauss SC (2010) Quantitative measurements of the optokinetic response in adult fish. J Neurosci Methods 186:29-34. CrossRef Medline

Neuhauss SC, Biehlmaier O, Seeliger MW, Das T, Kohler K, Harris WA, Baier H (1999) Genetic disorders of vision revealed by a behavioral screen of 400 essential loci in zebrafish. J Neurosci 19:8603-8615. Medline

Nishiwaki Y, Komori A, Sagara H, Suzuki E, Manabe T, Hosoya T, Nojima Y, Wada H, Tanaka H, Okamoto H, Masai I (2008) Mutation of cGMP phosphodiesterase 6alpha'-subunit gene causes progressive degeneration of cone photoreceptors in zebrafish. Mech Dev 125:932-946. CrossRef Medline

Oh EC, Khan N, Novelli E, Khanna H, Strettoi E, Swaroop A (2007) Transformation of cone precursors to functional rod photoreceptors by bZIP transcription factor NRL. Proc Natl Acad Sci U S A 104:1679-1684. CrossRef Medline

Orger MB, Baier H (2005) Channeling of red and green cone inputs to the zebrafish optomotor response. Vis Neurosci 22:275-281. Medline

Otteson DC, Hitchcock PF (2003) Stem cells in the teleost retina: persistent neurogenesis and injury-induced regeneration. Vision Res 43:927-936. CrossRef Medline

Papermaster DS (1995) Necessary but insufficient. Nat Med 1:874-875. CrossRef Medline

Phillips MJ, Otteson DC, Sherry DM (2010) Progression of neuronal and synaptic remodeling in the rd10 mouse model of retinitis pigmentosa. J Comp Neurol 518:2071-2089. CrossRef Medline

Ramachandran R, Fausett BV, Goldman D (2010) Asclla regulates Müller glia dedifferentiation and retinal regeneration through a Lin-28dependent, let-7 microRNA signalling pathway. Nat Cell Biol. 12: 1101-1107. CrossRef Medline

Raven MA, Oh EC, Swaroop A, Reese BE (2007) Afferent control of horizontal cell morphology revealed by genetic respecification of rods and cones. J Neurosci 27:3540-3547. CrossRef Medline

Raymond PA, Rivlin PK (1987) Germinal cells in the goldfish retina that produce rod photoreceptors. Dev Biol 122:120-138. CrossRef Medline

Raymond PA, Barthel LK, Curran GA (1995) Developmental patterning of rod and cone photoreceptors in embryonic zebrafish. J Comp Neurol 359:537-550. CrossRef Medline

Rivolta C, Sharon D, DeAngelis MM, Dryja TP (2002) Retinitis pigmentosa and allied diseases: numerous diseases, genes, and inheritance patterns. Hum Mol Genet 11:1219-1227. CrossRef Medline

Roger JE, Ranganath K, Zhao L, Cojocaru RI, Brooks M, Gotoh N, Veleri S, Hiriyanna A, Rachel RA, Campos MM, Fariss RN, Wong WT, Swaroop A (2012) Preservation of cone photoreceptors after a rapid yet transient degeneration and remodeling in cone-only nrl-/- mouse retina. J Neurosci 32:528-541. CrossRef Medline
Saszik S, Bilotta J (1999) The effects of temperature on the dark-adapted spectral sensitivity function of the adult zebrafish. Vision Res 39:10511058. CrossRef Medline

Schmidt TM, Do MT, Dacey D, Lucas R, Hattar S, Matynia A (2011) Melanopsin-positive intrinsically photosensitive retinal ganglion cells: From form to function. J Neurosci 31:16094-16101. CrossRef Medline

Schmitt EA, Dowling JE (1999) Early retinal development in the zebrafish, danio rerio: light and electron microscopic analyses. J Comp Neurol 404: 515-536. CrossRef Medline

Schroeter EH, Wong RO, Gregg RG (2006) In vivo development of retinal ON-bipolar cell axonal terminals visualized in nyx::MYFP transgenic zebrafish. Vis Neurosci 23:833-843. Medline

Schultz K, Goldman DJ, Ohtsuka T, Hirano J, Barton L, Stell WK (1997) Identification and localization of an immunoreactive AMPA-type glutamate receptor subunit (GluR4) with respect to identified photoreceptor synapses in the outer plexiform layer of goldfish retina. J Neurocytol 26:651-666. CrossRef Medline

Sekirnjak C, Jepson LH, Hottowy P, Sher A, Dabrowski W, Litke AM, Chichilnisky EJ (2011) Changes in physiological properties of rat ganglion cells during retinal degeneration. J Neurophysiol 105:2560-2571. CrossRef Medline

Specht D, Tom Dieck S, Ammermüller J, Regus-Leidig H, Gundelfinger ED, Brandstätter JH (2007) Structural and functional remodeling in the retina of a mouse with a photoreceptor synaptopathy: plasticity in the rod and degeneration in the cone system. Eur J Neurosci 26:2506-2515. CrossRef Medline

Stearns G, Evangelista M, Fadool JM, Brockerhoff SE (2007) A mutation in the cone-specific pde6 gene causes rapid cone photoreceptor degeneration in zebrafish. J Neurosci 27:13866-13874. CrossRef Medline

Stell WK (1978) Inputs to bipolar cell dendrites in goldfish retina. Sens Processes 2:339-349. Medline

Strettoi E, Pignatelli V (2000) Modifications of retinal neurons in a mouse model of retinitis pigmentosa. Proc Natl Acad Sci U S A 97:11020-11025. CrossRef Medline

Strettoi E, Porciatti V, Falsini B, Pignatelli V, Rossi C (2002) Morphological and functional abnormalities in the inner retina of the $\mathrm{rd} / \mathrm{rd}$ mouse. J Neurosci 22:5492-5504. Medline

Strettoi E, Pignatelli V, Rossi C, Porciatti V, Falsini B (2003) Remodeling of second-order neurons in the retina of $\mathrm{rd} / \mathrm{rd}$ mutant mice. Vision Res 43:867-877. CrossRef Medline

Strettoi E, Mears AJ, Swaroop A (2004) Recruitment of the rod pathway by cones in the absence of rods. J Neurosci 24:7576-7582. CrossRef Medline

Sullivan RK, Woldemussie E, Pow DV (2007) Dendritic and synaptic plasticity of neurons in the human age-related macular degeneration retina. Invest Ophthalmol Vis Sci 48:2782-2791. CrossRef Medline

Tagawa Y, Sawai H, Ueda Y, Tauchi M, Nakanishi S (1999) Immunohistological studies of metabotropic glutamate receptor subtype 6-deficient mice show no abnormality of retinal cell organization and ganglion cell maturation. J Neurosci 19:2568-2579. Medline

Terzibasi E, Calamusa M, Novelli E, Domenici L, Strettoi E, Cellerino A (2009) Age-dependent remodelling of retinal circuitry. Neurobiol Aging 30:819-828. CrossRef Medline

Vihtelic TS, Hyde DR (2000) Light-induced rod and cone cell death and regeneration in the adult albino zebrafish (danio rerio) retina. J Neurobiol 44:289-307. CrossRef Medline

Westerfield M (1995) The zebrafish book. Eugene, OR: University of Oregon.

Williams PR, Suzuki SC, Yoshimatsu T, Lawrence OT, Waldron SJ, Parsons MJ, Nonet ML, Wong RO (2010) In vivo development of outer retinal synapses in the absence of glial contact. J Neurosci 30:11951-11961. CrossRef Medline

Yazulla S, Studholme KM (1999) Co-localization of shaker A-type K+ channel (Kv1.4) and AMPA-glutamate receptor (GluR4) immunoreactivities to dendrites of OFF-bipolar cells of goldfish retina. J Neurocytol 28:63-73. CrossRef Medline

Yazulla S, Studholme KM (2001) Neurochemical anatomy of the zebrafish retina as determined by immunocytochemistry. J Neurocytol 30:551-592. CrossRef Medline 